\title{
Personal Citation, Rhetorical Practice and the Reinvention of Oríkì Tradition
}

\author{
Henri Oripeloye*, Folasade Hunsu \\ Department of English, Obafemi Awolowo University, Ile Ife, Nigeria \\ Email: ^oripeloyehenri@gmail.com, „horipeloye@oauife.edu.ng, fohunsu@oauife.edu.ng, fohunsu@gmail.com
}

How to cite this paper: Oripeloye, H., \& Hunsu, F. (2021). Personal Citation, Rhetorical Practice and the Reinvention of Oriki Tradition. Advances in Literary Study, 9, 159-172.

https://doi.org/10.4236/als.2021.94018

Received: May 4, 2021

Accepted: August 13, 2021

Published: August 16, 2021

Copyright $\odot 2021$ by author(s) and Scientific Research Publishing Inc. This work is licensed under the Creative Commons Attribution International License (CC BY 4.0).

http://creativecommons.org/licenses/by/4.0/

(c) (i) Open Access

\begin{abstract}
This essay responds to the shaping influence of Yorùbá oríki on personal citation, a written text that constructs individual identity in contemporary time. It reads personal citation as a cultural production that is realised through performance. Through a close reading of two purposively selected citation texts, the essay examines the various angles of interpolations between this written literature and the rhetorical practice of Yoruba oriki. Specifically, it explores the use of oral features such as animated speech, histrionics, and narrative aesthetics, and direct discourse in its delivery and proposes that the construction of social eminence in personal citation depends largely on praise chants. It concludes that there is a noticeable appropriation of the linguistic and textual context of panegyric to which shows personal citation as a hybrid text that contests cultural homogeneity and textual boundaries as it operates within the logic of complementarity in its poetic reflections and linguistic manipulations.
\end{abstract}

\section{Keywords}

Personal Citation, Oríki, Inter-Textuality, Rhetorical Nuances, Literature

\section{Introduction}

The complex and intricate relationship between orality and the written mode of communication has been the focus of scholars (Finnegan, 1976; Ong, 1982; Barber, 2005; Okpewho, 1992) but little attention has been paid to the conceptualization of written personal citation as an oral text. Personal citation would normally refer to either "a legal" or "bibliographical" process whereby a list of sources is cited in a document. But in Nigeria, it is understood to mean the biographical sketch of an awardee/speaker that is usually read aloud before a live audience to precede the conferment of an award or the delivery of a special lec- 
ture. (Adeeko, 2017) describes it as a text that "hybridizes what in other places is known as guest speaker's introduction and special honoree's profile read at academic convocations." Adeeko's exposition of personal citation as a cultural product of contemporary Yorùbá society structured to praise individuals agrees with our position in this paper that this sub-genre of biography could be located within the same cultural context where the performance of praise poetry, particularly, oríki is found. In Nigeria, occasions such as birthdays, anniversaries, awards, investitures, swearing-in-ceremonies, inaugural lectures and political rallies are not complete without the performance of citation. Therefore, this essay attempts to discuss the nexus between personal citation and oríki bearing in mind the status of the former as an amalgam of oral and written cultures. Praise poetry is a popular genre that is generously addressed to people, animals, trees, rocks and other natural objects. Oríki is a genre of praise poetry which refers to the praise names or attributes that are used to describe a person, lineage or a community. Among the Yorùbá, everything-animate and inanimate has an oríki, and as a corpus of social engagement, it helps in the delineation of a subject's feelings and thoughts as far as certain societal issues are concerned. The chanting of oríki confers social recognition on a personality since everybody has an oríki but not everyone is privileged to be recognised at a social function, hence chanting one's oríki becomes a mark of class within the conventional domain of everyday speech. Within the performance structure of oríki, there is marked evidence of the presentation of people's belief systems in terms of honour, heroism and valour.

Just like other Yorùbá art forms, oríki has undergone some innovations as a response to modernisation; this becomes necessary as this tradition struggles to remain relevant in the face of overarching western values. In traditional Yorùbá society, there is a group of people trained as bards or griots who sing the praises of the aristocratic class, courageous hunters, priests and the wealthy. There are also praise singers who specialise in providing unsolicited praises at ceremonies for gratification. But modernisation, with the advent of scribal culture has caused a change so that we now have educated professionals who are specialists in speech writing and delivery, including personal citation.

As a form of social praxis, personal citation articulates public discourse where social, political and cultural beliefs and practices are viewed from the perspective of a personality through the manipulation of communicative agency in order to curry recognition, acceptance and support for the subject of praise. In other words, the performer is involved in a conscious persuasion through seductive rhetoric to reveal the transformation of their subject from grass to grace. Hence, (Moraes-Farias, 1995) observes that what praise discourses postulate is their capacity to "seize upon the 'truth' of the praisee's being, activate it and generate acknowledgement of it by the praisee's private self and by the public at large. To achieve this, praise operates on 'the individual' not as if on an entity primarily defined by its boundedness, but rather as if on one whose singularity is constituted precisely by its participation in what lies beyond its 
boundaries."

The development of personal citation as a form of social entertainment in Nigeria can be linked to the rise of the middle class as a result of economic prosperity of the 1970s (Mosobalaje, 2007). The oil boom of the period ushered a new class of wealthy elites who at every opportunity displayed their economic power. In addition to this group were the educated elites who had obtained University education and most likely participated in the nationalist movement for the independence of the country from colonial powers. These were professionals, civil servants and politicians who had emerged as community and national leaders and it was not out of place to honour them as the opportunity presented itself.

Like other popular art forms, personal citation draws its significance from adulation of eminent persons-people of extraordinary achievements. Two of the factors that define eminent persons in Nigerian societies are the quantum of wealth accumulated by the individual and the impact they have made in their immediate and remote communities. Even in cases where the eminent person is not wealthy in material terms, they must have over the years participated actively in events that have had a direct impact on the community.

Personal citation is tailored toward action, and this is the concretization of the subject and the construction of power of representation because it dwells on the constellation of individual's achievements and experiences that distinguish one person from others. It is a medium for presenting the credentials of the celebrant or subject that make them qualify for celebration or as a speaker at an important forum. In addition, its "main purpose is to nurture the dissemination and perception of respectful regard for its subject, a subject worthy of being singled out for recognition and adulation at a public event (Adeeko, 2017)." It is the history of a courageous life who traduced the vicissitudes of life to become great. In terms of content and mode of delivery, citation reflects much of the glamour that is associated with the notable, it is therefore no wonder that the subject of attraction are the rich politicians, musicians, affluent businessmen and high-ranking civil servants. As a rhetorical practice and oratorical text, word formation and choice in personal citation are skilfully done as "a way of carrying out audiences to ratify particular visions, collectivities, subjects and ideologies embodied in textual significance for those who experience them (Gencarella, 2009)."

\section{Theoretical Framework}

The study applies rhetorical theory to discuss the interrelations between written personal citation text and the Yorùbá oríki. Rhetorical theory originated from Greece where it was used primarily in the courts, political engagements, and social functions for the purpose of persuasion but in contemporary time, it is about everything in terms of human discourse (Foss, 2009). Rhetoric has become a discipline that is grounded on the power of language which is used in the expression of ideas in various human activities such as writing, speaking, painting and 
drawing. From (Foss, 2009) perspective, rhetorical theorists are concerned with how "some or all parts of the rhetorical situation-the rhetor and the degree of agency available to him or her; the audience and all the constraints available to them; the discourse, message, or symbols used to address the exigence, how the exigence itself is constructed, created, and addressed; and the larger contexts-historical, economic, cultural, and symbolic, in which the situation is playing out." The exigence as the determining factor of tellability in the communication process demands that a rhetor attends to the challenging and often exhilarating and testing complexities in persuading the audience to respond positively to a piece of presentation or performance.

Furthermore, rhetoric helps in defining the relationship between the subject and the speaker on the one hand and the speaker and the audience on the other hand in the construction of the subject being-ness and the audience social awareness. Identification of the audience configuration helps the speaker to present what is expected in order of value-social, cultural or political, by the audience, in other words, the speaker creates a bond between the audience and their subject. This process of bonding thrives on the use of "vivid metaphors, creative interpretation of evidence, arresting figures of speech, irony, humor, exaggeration, gestures, performance, and dramaturgy" (Dryzek, 2010). Therefore, within the field of rhetorical criticism, personal citation is an oratorical piece that cannot but depend on rhetorical affects. (Gates, 1988), in his seminal book, The Signifying Monkey claims that a speakerly text uses rhetorical devices which are designed to produce phonetic, grammatical and lexical patterns of actual speech commonly seen in oral narration. He goes further to assert that "the speakerly text is that text in which all other structural elements seem to be devalued, as important as they remain to the telling of the tale, because the narrative strategy signals attention to its own importance, an importance which would seem to be privileging of oral speech and its inherent linguistic features." These oral features include but are not limited to the use of animated speech, histrionics and narrative aesthetics, direct discourse, architectonic patterns and framed narratives. The analysis of the data in this work is subsumed within the parlance of rhetoric theory to enable us show how a written text evinces sense of orality to identify with (Kaufer \& Kathleen, 1993) and Kathleen's submission that "writing did not squelch speaking but created new contexts for speech." The words on the pages are recognised as symbols for persuasive discourse in the presentation of a person of achievement. It is therefore, the duty of the rhetor to define how the audience perceives the subject. This is achieved by the creation of lasting impressions in the mind of the listeners with use of symbolic narrations which produce new thoughts that may generate new perception leading to expected actions from the audience.

\section{Exploring Inter-Texuality and the Rhetorical Practice in Personal Citation and Oríkì}

The interdependence of literary works foregrounds the fact that no literary com- 
position is an orphan, there is always a trace of formal creative negotiation between forms of artistic creativity, hence (Izevbaye, 1982) sees inter-textuality as a "weapon in the hands of literary historians and critics to establish a relationship among a variety of writers and literatures." Therefore, literary historians are involved in discovering literary syncretism in texts by making adventures into the past in order to identify convergences between texts. This location of textual relationships imbued literary texts with fluid identities to the effect that it is difficult to find an autotelic text that is free from textual interpolations. This position is supported by (Kristeva, 1980) when she opines that "all signifying systems are constituted by the manner in which they transform earlier signifying systems." She therefore defines a text that is imbued with inter-textual qualities as "any text (that) is constructed of a mosaic of quotations; any text (that) is the absorption and transformation of another" (66). (Olson \& Torrance, 1982) have also pointed out that "developmental studies of the relation between oral and written language have found that rather than these being categorically different modes, there is a close interaction between the two... Literacy is built upon a strong oral tradition and thrives only if a living oral culture sustains it."

Personal citation is an art form that concretizes the values and imagery of performance. Without the text, it seems the performance is doomed to fail, even in a purely oral delivery, there exists a text or a pool of texts from which the performer recalls events, and improvisation only provides a vehicle for the expansion and easy delivery of such texts. (Barber, 2005) distinguishing between text and performance claims that while text is a permanent artefact, performance is the realisation of the text. Barber's position does not provide a neat taxonomy, the interplay between text and performance is complex and the level of inter-textuality in these forms is self-evident as one vivifies or animates the other and in spite of her earlier conjecture, (Barber, 2005) concedes that "written texts can be cues, scripts, or stimulants to oral performance, and can also be records, outcomes, or by-products of it. Even texts usually thought of as belonging purely within the written sphere can have a performative dimension."

Personal citation as a literary production possesses the features of a literary tradition that (Ong, 1982) describes as rhetorical culture and which (Paulson, 2001) explains as "an early modern form of cultural organization that, while largely realized in writing and even print, was still strongly nourished by its roots in orality: In storytelling, oratory, preaching conversation and other genres of the spoken word." In addition, like oral performance, personal citation when considered within the ambit of its polysemous performance nuances is quite enigmatic and puzzling. But more importantly, certain features of oral performance are manifested in written personal citation: improvisations, apostrophic references, digressions and outlandish eulogies. These elements are constantly deployed by the citation performer in the construction of the subject's life. That personal citation shares mode of presentation with the panegyric is accounted for by the fact that panegyric has no fixed corpus; its manifestation is evidenced 
in almost every human speech act. (Adeeko, 2012) touches on this claim when he points out that "the Yorùbá panegyric is a supple and versatile form that has always been open to reinterpretation and improvisation." The transformation of panegyric from folkloric performance to the written mode or modern stage in form of personal citation is no doubt an ingenious means of preserving its continuity in the expression of social and political power game in which communicative manoeuvre is deeply concerned with the propagation of selfimage.

One can therefore argue that oral performance as popular art form influences the structure of personal citation, especially in the area of stylistic choices at the disposal of the oral performer. Personal citation reflects much of African oral poetics; proof of this is the imitation of the oriki tradition in form and style and especially its proclivity towards appellation poetry which "forces one to acknowledge not only orality in writing, but also aurality in reading" (Adu-Gyamfi, 2002). There is a noticeable overt utilization of generic codes that are mainly identified with oral performance which are converted to exotic romance in personal citation as the celebrant is magnified in order to create a social class for him/her. In such presentations, emphasis is placed on "all facets of the public delivery of a speech, including timing, the use of pause, and the manipulation and control of a speaker's voice to create special audio effects, as well as the use of non-verbal communication through facial expressions, hand and body movements, and strategic spatial positioning" (Wendland, 2012).

The conceptual understanding of personal citation demands a close reading of selected written texts in order to account for the intertextual elements between personal citation and panegyric. We propose that the construction of social eminence in personal citation depends largely on praise chants. The implication of this inter-textuality is that "oral traditions appear in written texts and written traditions are heard in oral texts" (Ighile, 2013). Personal citation is a written composition that cannot be fully realized without performance, meaning that the text of personal citation has no existence outside the performance of the text. It is simply a text that is written for performance and it emulates the oríki tradition among the Yorùbá, the izibongo in Zululand and the epic in Mali. All these praise poems are composed and used to eulogise individuals, the community and the terrestrial bodies, including animals and trees. With the influx of written texts, there is every possibility that people may be "disconnected from the affairs of the city, the marketplace, and the natural world; from aspects of life that are all too easily written off as common, vulgar or overly material (Paulson, 2001)", but personal citation, though a written text, safeguards the society from derailing further from the "natural world" as its contents and forms animate our world by revisiting the earlier narratives that are easily identified as belonging to the oral world.

The successful performance of personal citation depends on the creative propensities and energy of the performer. Therefore, the choice of the citation performer is a carefully wrought assignment as organizers of the event would not 
want to risk having a bad outing because of the inadequacies of the performer. The performer is usually a known figure within that community, possesses oratory skills, and is able to command and weave words to achieve the desired effect on the audience. In some cases, these are professionals who receive monetary rewards for their performances.

In oral performance, vocalization reflects the different types of voice modulation in poetic performance and in Yorùbá oral performance, each voice is a distinct element of a genre. In citation performance, there is avalanche of voices at the disposal of the performer; they vary the manner of their poetic articulation to highlight a particular element of information in the performance. There may be a shift from the high-pitched voice of ijalá or ofo chanter to the lullaby tune of orin aremo. The choice of grammatical forms is also dictated by the laudatory intent of the performance so that metaphors and outlandish exaggerations are common choice for the descriptions of the subject's attributes. These qualities are usually loaded with praise-graphic signifiers that include "a series of pictures (that) is conveyed to the listeners through a number of laconic and often rather staccato sentences, a grouping of ideas which may on different occasions come in a different order" (Okpewho, 1992). In this regard, a person that smiles always is described as elérin-ín èye (owner of befitting smiles), a black person is adúmáradán (the dark-skinned one whose body shines), a tall person is aguntạsoólo (the tall one who cloths fit) and someone with shining white teeth is eyínfúnjowo (the one whose teeth are whiter than cowry-money). Performance in these social texts creates excitement through sentimental utterances in order to enhance the public and social ratings of the subject of the performance. Award ceremonies are used to eulogise the achievement of honour and fame and personal citation is used to mark such occasion in order to convince those present that the subject actually deserves such celebration. The subjects of the citation are often in metaphorical terms compared to living heroes or departed legends such as Martin Luther King, Ọbáfémi Awólọwọ, Nelson Mandela, Sàngó, Ògún or may be synecdochally referred to as a lion, tiger or elephant depending on the aspect of their character such as strength, courage, valour, generosity that is being promoted. In this wise, personal citation "creates mythic personages by simply 'containing' them in a box-like space, where they are seen as suspended in real time and space, in a mythic world of their own (Danesi, 2004)."

Having explored the symbiotic relationship between written citation and oral performance, we shall now address the nature and aesthetics of this hybridization of genres by analysing two citation texts. There are two reasons for this choice: first, these texts have explicit inter-textual relations to oral delivery being a text configured for the ear and second, there is the network of features associated with the Yoruba oriki social culture that is pervasive in the performance modes of personal citation. The aim of the analysis is to highlight the privileged position of panegyric in written personal citation as may be seen in a situation where equestrian image is created by the invention of fantastic roles in order to carve the figure of an extraordinary character out of the subject. The selected 
texts are rhetorical tour de force and carefully wrought expose on the social standing of the subjects, who have achieved so much that they have transformed themselves to the realm of the eminent persons in the society. To be clear, their citations were performed on different occasions: Professor Ojerinde was a guest lecturer at a round table discussion organised by members of a social club in a University while Madam Ayo was the guest lecturer at a commencement ceremony of a university. The universities are in south west Nigeria. Both subjects are first properly located within the social and cultural contexts to which they have been invited and as a way of connecting to these contexts, the early part of their citations state their "origins". "Professor hails from" and Madam is introduced as being "born into the royal family of..." Each of them is first identified with their roots because the naming of a subject's origin is a critical emblem of the Yorùbá culture and especially the hallmark of oriki, which is a genre of origins. It is common among the Yorùbá to ask "omo ta ni?" (whose child is s/he?) so that the subject could be properly profiled.

The Professor and Madam are presented as "heroes", a term, which in Nigerian culture has undergone meaning transfer to include exceptional entrepreneurs, astute scholars, valiant soldiers and accomplished civil servants. What is being underscored in the extension of heroism to cover these spheres are special instances of ingenuity and accomplishments which may not necessarily include personal sacrifice. Their citations project them as achievers who have traversed all odds to become pioneers of uncommon successes and acts. In other words, they are no longer ordinary man and woman but persons to be acknowledged, respected and praised for moving beyond the rank and file to the heights they have attained. This probably accounts for listing of academic qualifications and special mention of local and foreign institutions from where they obtained them.

The opening framing of the performance, like the Yorùbá oriki presents the Professor and Madam to the public through naming. Suspense is woven around this framing so that a narrative affinity with the rest of the performance is established, a further narration of their eminence to show their standing in the society. The citations of both subjects highlight different awards given to them within and outside Nigeria, the highest of the latter being the National Honours Award of the Officer of the Order of the Niger (OON), one of the most prestigious awards in the nation. In laudatory statements, the Professor is further introduced to the audience as "distinguished scholar and seasoned administrator" while Madam is "a highly rated civil servant". Through an additive construction that creates a piling effect, the citation performers recount pace setting acts of the subjects. The Professor is the first in his field of specialisation and the first director of a number of national establishments viz, "Nigeria's first Professor of Tests and Measurements, first Director of Monitoring and Evaluation Commission, first Director/Consultant of the Centre for Educational Measurement, first Registrar of the National Board of Educational Measurement, and first Registrar of National Examination Council (Profile I, 2015).” The Madam made national history by being the "first woman to visit North Korea in an official capacity, the 
first woman to be appointed the Chairman of the Federal Civil Service, and the first woman from Saki to become a Permanent Secretary in a Federal Ministry in Nigeria (Profile II, 2019)." The adjective "first" is repeated several times in their citations to provide unique information about the leading roles they have played in various capacities. The repetition is used to describe their exploits and "when placed side by side", according to (Finnegan, 1976), it "adds to the impression of the achievement." The positioning of "first" at the beginning of the phrases heightens the performative effect as such repetition/piling when produced orally creates emotional response and the audience responds by clapping of hands and shouts of admiration. Without performance, such repetition would have been monotonous but in these instances, it oils the performance as noted by (Gerdes, 1990) when he opines that, "oral cultures depend heavily on repetition and redundance (sic) in order to sustain an unbroken process of thought." In the portrayal of the Professor, the emphasis is drawn on his ability to be a pioneer of some important education parastatals; he is not just a professor but someone whose ability has been identified as a fore-runner of essential educational services in the country. It should be noted that the narrative is a textual explication of the content of the citation as revealed by the rhetor but an interpretation from the connotative standpoint will however show that beyond this rhetoric of branding is the unspoken promotion of the subject and thus confirming (Barber, 2007) statement that "the hallmark of African praise poetry, is the laconic formulation that can only be interpreted in the light of a narrative or a highly specific circumstance that is not implicit in the words themselves."

Next is the aggregation of the subjects' excellent performances in those places they held their "firsts". In framing this narrative, the performers present the ideals, the expected markers of success without which people who have reached such heights will not be recognised. The information is collected as group to emphasize them in terms of quantity and possible quality. The group contains the innovations they brought to the bodies or ministries they headed. The ability of the Professor and Madam to successfully introduce these innovations in environments where innovations are sometimes resisted portrays their heroic figures. The Professor's trailblazing fight against examination racketeering, unimaginable malpractices, and delay in results or outright cancellations of examination results is given ample attention during the performance. As the head of an examination body, he brought innovations such as releasing results within a week which he ups to a day in subsequent years. His innovation further introduced biometric data capturing and verification to check examination fraud, he also introduced the novel computer-based test for examinations in Nigeria. These are no mean achievements going by what examination bodies in Nigeria had suffered in the past. For anyone to put a check on all these maladies demand great foresight and courage which have been identified in the Professor by the performer. An avenue such as this provides that chance for him to be celebrated. It is therefore, no wonder that the performer in an effort to showcase all these achievements pushes the audience through an assemblage of layered narratives 
emanating from different experiences of the subject.

The cultural and social contexts serve as backgrounder and become significant in the homage paying enacted by the performers of the citations as certain cultural valuations in the unconscious moments of the subjects' development are recalled to show the shaping influence of the environment on them. Place of birth, education and work experience become touchstones to greater heights and these are presented to load them with unique qualities. For instance, the Professor was born in Igboho, a rural enclave in Òkègùn in Ọyó State, when placed in contrast with say İbàdàn or Lagos which are urban centres, Igboho becomes more alluring and engaging when someone from a remote village is at the forefront in the moulding of policies that affect everyone. He is therefore presented as a good ambassador of his village as far as his public image is concerned. His choice of educational institutions is used by the performer to promote his social status as he did not attend just any university but one of the first-generation universities in the country after which he travelled abroad for further studies. The performer extrapolates on these facts so that the audience will be familiar with the knowledge worth of the Professor who has been selected as a guest speaker in an academic community. One other area that is emphasised is the publishing profile of the subject, he has published more than 150 items which include books, monographs and articles, and hence he is a prolific writer, a term that distinguishes hard working scholars from lazy ones. His supervision of many students at the postgraduate level has earned him the accolade professor of professors which in oral tradition is a form of appellation cognomen that is earned from colleagues and admirers. Beyond admiration, appellation is the attribution of qualities in terms of personality traits-hard work, discipline, prudence and generosity; it also confirms notions of acceptability on a personality who is able to mentor people to reach the peak of their career. On the part of the Madam, she also graduated from a first-generation University in Nigeria in the nineteen sixties at a time when University education was a male preserve. She also travelled outside Nigeria to obtain postgraduate degrees and relevant trainings in business administration and diplomacy. According to the citation, "she also had In-Service Courses in Administration and Finance in University of Massachusetts, Amherst, USA, University of Manchester, United Kingdom and IMEDE, Switzerland (Profile II, 2019).” Her courage and greatness are underscored in the reference to the reforms and innovations she introduced to the Federal Civil Service such as: merit-based promotion exercise on annual basis; advertisement of vacancies and on-line recruitment, disciplinary cases judiciously handled thereby minimizing litigation, review of guidelines on recruitment, promotion and discipline, to ensure a balance in reward and sanction, strict adherence to rules and regulations and extant circulars in the conduct of activities at the FCSC (Federal Civil Service Commission), introduction of performance contract as a means to measure effective performance and timeliness; and re-enactment of the core values of the public service.

The Professor and Madam having achieved all the above, are recognised as 
prominent members of professional bodies, president and vice president of clubs and societies and board members of organisations owing to their track record, pedigree and prodigy. These words are chosen to reflect the oríki mode where a person's capability is celebrated in order to accentuate a feeling of gratitude from the subject. They both have received numerous national and international awards and distinctions, letters of commendations, opportunities to represent the country at important academic and diplomatic fora. The attendance of international conferences in countries such as USA, Canada, UK, Australia, France is also well highlighted in their citations. Their praise would have been incomplete without showing how widely travelled the subjects are. Recognition has been given to Professor by traditional rulers from his home town as Olunla of Igboholand and the Ọọni of Ifè as Àre Fìmọgboyè of the source. His achievements are celebrated as his academic exploits, national and his traditional recognitions are recounted when the performer, using generic performance codes referred to him as distinguished scholar, seasoned administrator, prolific writer and visionary leader.

Madam also occupied many prominent positions in her public service career and these are well noted by the performer.

As a highly rated civil servant, she served in various Federal Government Ministries, including Ministry of Trade, Commerce and Industries (1977-1983), Ministry of Finance (1984-1986), Office of the President (1986-1994) where she served in different capacities, i.e. Secretary for Finance and Administration (GL. 16) and became a Director (GL. 17), in 1988. She was appointed Permanent Secretary in 1992. During the course of her Civil Service Career, she represented the Federal Government at several International Conferences and Meetings in different parts of the world, including the famous European Economic Forum, Davos, Switzerland Business Forum, Antwerp, Belgium and Conference on apartheid in Hove, Britain among others (Profile II, 2019).

Being a retired civil servant, her achievements and greatness are measured in terms of the positions she occupied while in service and her grade level at each point. These indices underscore the uniqueness of Madam's attainment and the appreciation of the unspoken quantum of hard work that must have preceded each achievement.

Since personal citation is composed to be heard and being an oral text consigned to print, its delivery necessarily must take into account certain performance indicators such as the manner of voice articulation, the pace of the performance, histrionics and gestures, hence (Blount, 1992) has theorised that "in written texts that draw on the aesthetics of vernacular performance, the relations of orality and literacy are continuous. The tensions between repetition and improvisation that operate in a verbal performance are translated into competing structures of creation and recollection for literary artists and their audiences." The performer relies heavily on animated speech, narrative permutations, a col- 
lage of adulatory epithets and laudatory coinages which are common indices in oriki in the construction of the identity of the Professor and the Madam.

\section{Conclusion}

Our foregoing discussions show the convergence between personal citation and the oriki tradition despite the former's written context. This nexus is facilitated by the contents and the performance structure of personal citation which shows forms of eclecticism and dynamism associated with oral performance. The hallmark of personal citation is praise performance which is constructed in the image of the praise through a constellation of descriptive epithets that bring the positive life of the subject to the fore. The performer constructs his subject's biographical selfhood by ascribing incongruous title(s) to him as he narrates the story of his life from the point of adulation. And typical of life writing, these narrations are mediated to reflect events that promote the subject, not an accurate reconstruction of past events since "there is always a room for subtle modification, unintended misrepresentation and sometimes deliberate distortion of reported events in any historical account (Ngwenya, 1999)." The concern with reconstructing the relationship between oral and written texts often engenders complex re-evaluation in relation to the new perspective that has been discovered in the operational modes of these interactions. In this study, the age long dichotomy plaguing the discourse has been further exposed as a nebulous engagement as has been demonstrated in this occasional text. Within the context of performance studies, personal citation occupies a space that requires critical insight in order to discover how a text moves from its fixed provenance to betray those features noticeable in the performance of oriki. By transfiguring personal citation into performance, the performer has re-enacted the place of orality in a thriving literary culture to the effect that the Yorùbá oriki tradition is manifestly used by literary artist in a formal mode encapsulated in written personal citation. Therefore, scholars of oral literature might want to direct their searchlights on other occasional written texts in order to explore the dynamics of cultural narrative form in these literatures.

\section{Conflicts of Interest}

The authors declare no conflicts of interest regarding the publication of this paper.

\section{References}

Adeeko, A. (2012). Panegyric and Photography in Contemporary Lagos, Nigeria. Critical Inquiry, 38, 330-361. https://doi.org/10.1086/662745

Adeeko, A. (2017). Arts of Being Yorủbá: Divination, Allegory, Tragedy, Proverb, Panegyric. Indiana University Press. https://doi.org/10.2307/j.ctt20060q5

Adu-Gyamfi, Y. (2002). Orality in Writing: Its Cultural and Political Significance in Wole Soyinka's Ogun Abibiman. Research in African Literature, 33, 104-124. 
https://doi.org/10.1353/ral.2002.0064

Barber, K. (2005). Text and Performance in Africa. Oral Tradition, 20, 264-277. https://doi.org/10.1353/ort.2006.0001

Barber, K. (2007). The Anthropology of Texts, Persons and Publics: Oral and Written Culture in Africa and Beyond. Cambridge University Press.

Blount, M. (1992). The Preacherly Text: African American Poetry and Vernacular Performance. PMLA, 107, 582-593. https://doi.org/10.2307/462763

Danesi, M. (2004). Messages, Signs and Meanings: A Basic Textbook in Semiotics and Communication. Canadian Scholars' Press Inc.

Dryzek, J. (2010). Rhetoric in Democracy: A Systemic Appreciation. Political Theory, 38, 319-339. https://doi.org/10.1177/0090591709359596

Finnegan, R. (1976). Oral Literature in Africa. Oxford University Press.

Foss, K. (2009). Rhetorical Theory. In Encyclopedia of Communication Theory (pp. 854-858). Sage Publications. https://doi.org/10.4135/9781412959384.n328

Gates, H. L. (1988). The Signifying Monkey: A Theory of African-American Literary Criticism. Oxford University Press.

Gencarella, S. (2009). Constituting Folklore: A Case for Critical Folklore Studies. Journal of American Folklore, 122, 172-196. https://doi.org/10.1353/jaf.0.0086

Gerdes, D. (1990). An Embattled Society: Orality versus Writing in Alicia Yanez Cossio's "the Sisterhood of Sacred Vestments of the Plump Virgin". Latin American Literary Review, 18, 50-58.

Ighile, M. (2013). Theorizing Language, Orature and the Bible in Africa. Nigerian Journal of Oral Literatures, No. 1, 129-143.

Izevbaye, D. (1982). The African Experience of Comparative Literature. In S. O. Asein (Ed.), Comparative Approaches to Modern African Literature (pp. 1-15). Ibadan University Press.

Kaufer, D., \& Kathleen, C. (1993). Communication at a Distance: The Influence of Print on Sociocultural Organisation and Change. Lawrence Erlbaum Associates.

Kristeva, J. (1980). Desire in Language: A Semiotic Approach to Literature and Art. Columbia University Press.

Moraes-Farias, P. (1995). Praise Splits the Subject of Speech: Constructions of Kingship in Manden and Borgu. In G. Furnis, \& L. Gunner (Eds.), Power, Marginality and African Oral Literature (pp. 225-243). Witwatersrand University Press.

https://doi.org/10.1017/CBO9780511521164.018

Mosobalaje, A. (2007). Oríkì, Juju and the Making of "Big Man" in Yorùbá Society. Papers in English and Linguistics, 7, 141-151.

Ngwenya, T. (1999). Orality and Modernity in Autobiographical Representation: The Case of Naboth Mokgatle's Life Story. In D. Brown (Ed.), Oral Literature and Performance in Southern Africa (pp. 111-131). James Currey.

Okpewho, I. (1992). African Oral Literature. Indiana University Press.

Olson, R., \& Torrance, N. (1982). The Making of Literature Societies. Blackwell.

Ong, W. (1982). Orality and Literacy: The Technologizing of the Word. Routledge. https://doi.org/10.4324/9780203328064

Paulson, W. (2001). Literary Culture in a World Transformed: A Future for the Humanities. Cornell University Press. https://doi.org/10.7591/9781501729348

Profile I: "Professor Dibu Ojerinde". 5th Roundtable, The Staff Club, Obafemi Awolowo University, Ile Ife, Nigeria. 6th June, 2015 (Transcript). 
Profile II: “Deaconess Joan Ayo". 14th Commencement Lecture, Bowen University, Iwo, Nigeria. 12th December, 2019 (Transcript).

Wendland, E. (2012). Poeticizing the Lord's Prayer for "Pronunciation". An Exercise in Oral-Oriented Bible Translation. Neotestamentica, 46, 394-415.

https://doi.org/10.1002/9781405198431.wbeal0089 